\title{
2 Sex (and Sublimity)
}

Its passions will rock thee

As the storms rock the ravens on high

P.B. Shelley

It is surely our number one pastime, our ruling obsession, our preferred patois; America is quite hopelessly all over, and into, and about, sex. Everyone's into it, quite without exception, and wholly without regard to political, or social, persuasion; liberals, conservatives, Seventh-Day Adventists, Hare Krishnas; civilians, army personnel, pensioners, retirees, the unemployed; blacks, whites, the undecided - but everyone. It's indeed quite impressive, and no other society quite matches up, even if it cared to; only in America do sexists, anti-sexists, feminists, chauvinists, vegetarians, and tee-totallers, all come together, in alleviative consilience, at least on this score, with one big sigh of relief. Just look around you: where isn't it happening? Sex is both medium and message, rite and ritual, sop and stimulus, market-wise connected with toothpaste, chewing gum, beer, cigarettes, cars, furniture, and outboard motors. Magazines, films, news-stands, bill-boards, books, and hoardings, are all chock full of the One Big Surreal Thing; no exaggeration at all: know anyone who doesn't want to be, look, and feel, and be regarded as, sexy? From seventeen year-olds (G ratings in movies are already a thing of the past) to seventy year olds, the great libidinal revolution was to sweep America quite off its feet while the rest of the world, in its perennial trauma of reactionary backwardness, was still pondering whether a revival of the circumspection of the middle-ages, in this regard, was not, still, a good idea.

Few, native to this continent, truly appreciate this all-pervasiveness of the sexual idiom, for being all but immured in it. Now, I myself come from (though admittedly it's only a distal memory now)a guilt-ridden, quasi-hypocritical, death-fearing, repressive, mostly non-capitalist, cultural milieu (where such matters were always shrouded by a veil of sheer embarrassed delicacy) - as indeed do millions of Africans, Asians, even some Europeans - still somewhat free of the grip of the great sexual Involution, and so still liable to blanche inwardly at the obtrusive display of that glaringly explicit sexual garnish that adorns all shades of American living, bumper stickers not excluded. Such manner of creatures, cast of primordial clay, dripping with prehistory, and culturally archaic, can only appear stodgy, old-fashioned, and out of it, set off against this grinding, frenetic, All-American, absorption - as off-the-wall, ill-fitting, peripatetic fauna sprung from a nether world, who wear not deodorants, watch not their figures, and curb not their artless body language; and who couldn't ever play up to that dark, sultry, and mysterious act, the average minimum that is de rigeur in this field of human affairs, if they took a college course in it.

And we all know, to our great comfort, how tacky they are; we who drive sexy cars, wear sexy clothes, read sexy magazines, live in sexy homes, and handle sexy gadgetry whether at work, play, or immersed, merely, in plain idleness. They are the 
paisanos and we, the high sophisticates - or so we imagine, to our own immense satisfaction (although the scenarios are altering quite rapidly: rabid, even grotesque, sexism is the growing rule in putatively 'liberated', neophyte East Europe, with Budapest setting the new, Vegas-like, anti-cultural standards for the region. Indeed, well before the Great Collapse, Milan Kundera had already defected to the West, in defense of his inalienably fundamental right to - yes - author: pornography).

But sex is one matter, satisfaction another. Open, flaunting, bare, strictly anatomical sexuality, coupled with the inescapables of coldness and distance, the almost unavoidable attributes of anonymous social life, of course, speedily kills off good feeling, good sense, and good camaraderie; to be sexy is not always to be available, or willing, or implying any of that 'come-hitherness' that was such a trademark of the way overdone vamp routines of the old pre-War movies, but, au contraire, to be icy, distant, unapproachable, self-contained, and narcissistic. It adeptly raises tensions, anxieties, and anticipations, but with little promise of any real redemption.

Human sexuality as an all-embracing, never-ending, never exhausted, running battle between the sexes is, at least to uncouth foreign eyes, largely an American cultural invention, with all its corresponding neuroses of anger, frustration and depression. In the extreme, it produces that hallmark savagery and violence that are so lovingly depicted in the ghastly, every-day, run-of-the-mill, catch-as-catch-can, totally irredeemable, yet standard, movie fare that Hollywood, thanks to the dvd/internet revolution, streams out so very efficiently, by the hour, every day of the year.

Of course, few societies, other than the fast disappearing tribal forms, have ever managed to be completely at ease with human sexuality, and sexual tensions exist in all contemporary societies (the Pleasure Principle rubs against the Work Principle, one might say, the wrong way). But to turn this apparently pre-given tension into a lifelong sexual addiction (itself tied to the marketing efforts of big business) is uniquely American; granted, looking for sexual fulfilment is surely permissible, and not finding it, possibly just as predictable - but to make this saga of seeking, and not finding, a permanent substitute for life is as American as the Flag, Hot dogs, and Coca-Cola.

Now, if your own sex-life is on ice, it doesn't much matter, really; there's always the sex-life of the (rich and) beautiful people to consider, vicariously. You know the gambit: I know someone who knows someone who knows all about Britney Spears'or J. Lo's - sex-life, from puberty to stardom, in grating detail. I also know someone who knew someone who dated Madonna's step-sister; and so on. Are we having fun, yet? You betcha!

Then there's the young woman I once knew, aeons ago, in New York, let's call her Darla, who, quite literally, tried on new partners every week(end). 'Why', I asked her, in my uncouth way; the question puzzled her immensely - 'What else is there?' she replied,' I mean, that's what it's all about, isn't it?' (Unknowingly, she was repeating Everest conquering - if you can believe that, as opposed to the doughty, Nepali Sherpas who virtually carried him there - and oh-so-very-English, Sir Edmund Hilary's famous riposte: 'because it's there'). It sounded ok, as appearances go; and you 
know what I mean; we have to find out who we are, who she is, who he is, what it's all about, don't we?; and we're all searching, aren't we? And I'll warrant, ten years down the line she'd still be 'searching'(the 'fun's in the searching, not in the finding; in this regard, en generale, one does not find, one seeks), in that spirited, if somewhat exhausting, way; actually, I do happen to know - I met her, ten years later, with her situation as ditto as it had ever been. Of course, she eyed me still, I fear, as a boorish conservative, a hangover from some past epoch, for being less than enthused about her wholly athletic, red blooded - and yes, the all-American, catch-all phrase will have to be used - 'life-style'.

No, I'm not preaching Monogamy, single partnership, or any other 'rule' of sexual relations and god knows (since I take time off to revile some of her creations every day!) I'm no to-the-manner-born conservative; and, leaving none too unhappily, a now only memorialized cultural India, with its traditional cruelty of suppressions in such matters, I would hardly be wedded to old-fashionism in these things. But let me, nevertheless, draw from India, to illustrate my meaning. By and large, metropolitan Indian society (quite large in numbers, and changing rapidly, at the present time) is/was highly hypocritical and conservative; sexual expression, before marriage, for my conjectural friend Kamala, for instance, is/was severely curbed, and sexual tensions accordingly are quite high amongst young people, generally. For a Kamala, like most, therefore, regular sexual intimacy begins usually after marriage, despite the odd 'affair' prior (though there is much growing latitude here today): and there's not tremendous scope for changing partners and seeking Mr. or Ms. Goodbar, usually.

Well, yes, freedom of choice is thereby a mite limited, and perhaps people do not have the opportunity to 'discover themselves', in this domain at least, to the degree possible for Darla, the New Yorker. However, once married, and with the fires of youth eventually abated, if not exhausted, the issue seems to die out quite decently, and lives are spent, usefully or not, seeking multiple avenues of contentment of a social/ cultural nature be it in family, partying, politics, art, drama, literature, etc. Darla, by no means atypical, on the other hand, was seeking (not discovery but dissolution, although she wouldn't know it) almost all her social stimulation in her sexuality, in her 'relationships', defined purely individually. Her 'social life' - and almost singularly, this phrase has come to mean, in context Americain, only sexual relations - was quite limited; whereas, the sexual life of the Indian women I know (yes, I speak only of the middle-to-rich classes here, the educated, etc.), and only as far as I know, is quite uninspired, though quite the contrary with their rich social range of involvements, associations, and commitments. Are the two women on par?

Let me explore further. Sex, as every schoolchild knows, is both a commodity i.e. it is bought and sold, like a haircut or a piano lesson - and a marketing tool. But, unlike the haircut or the piano lesson, it is not the service, but the server that is commodified. As the mainstream norm runs, women are the sex-objects, the servers, the ones who deliver; they are the ones bought and sold, used, abused, transported 
across state lines, raped, beaten, mutilated, tortured, and so forth. Their objectification, in social terms, is not always understood, surprisingly enough, even by women themselves. Darla, the New Yorker, thinks she is searching, within the vacuum of her search area, for the real thing; she is not aware that she is (in the discourse of patriarchy) the real, objectified sexual 'thing', in all of her interactions. She will deny it, of course, speaking lightly of her frequent (mis)adventures in this domain. But the sad fact is that, as an ancient saying goes, whether the melon falls on the knife, or the knife falls on the melon, usually, it is the melon that gets sliced. And you wonder: how can she deny the obvious? Read the papers, listen to the evening news, scan the magazines, go to a peep show; look to the ceaseless violence against women, whether as child, teenager, or adult, observe it in the streets, in boardrooms, bars, and toilets. How can Darla not know?

Easy, actually. She does not see the whole; society is a concept, a fiction. Her personal relations are real, tangible. The latter she can 'deal with', but the former is fit subject matter only for a college course, or an editorial in one of the insipid newspapers she reads (only casually). She understands only what (she thinks) she experiences; she competes with others of her own gender (like the doomed slave gladiators of Rome), and has, somewhat sadly, rather a low opinion of women. Besides, if she is to be believed, all the bad stuff that goes on is either chance, happens to others (other girls, in trouble, were always either 'asking for it', or were just plain 'dumb', or just didn't know 'where it's at'), or is just 'life' (and we all know 'life' is not fair', as Jimmy Carter once said, blandly, when unions once asked him for higher wages) - but not a specific structure of norms, mores, or social organization. She thinks she can handle herself; everything is compartmentalized, boxed, wrapped and separated; yes, Darla is 'ok' with herself. Or, so she imagines.

Let me tell you what happened one night, on a College campus, somewhere up East. Now this a true story, no allegory. It was dark, it was raining, and I was putting in some overtime in my office. There was a knock; it was Darla.

'Hi' she said, planting herself on my desk. She had a bottle of vodka which she thumped noisily on the glass-top.

'What's up?' I asked, wondering.

'Let's go someplace' she said, simply.

I must have been working too hard. I still didn't get it.

'Go where?' I asked, dumb as a post.

She looked at me like I was the feeble dweeb I was.

'I'm not taking your exam tomorrow' she said, arching her eyebrows.

'Oh?', I said, still not catching on.

'But I need a grade; so let's go to your place'. She smiled.

Darla was seventeen, then; even younger, actually, in her emotional make-up, but looking at her that evening, the way she was made up, she could have been a cut-out from any adult magazine. Indeed, the whole scene could have been in a movie. Later, she told me how she almost always got her grades that way. 'Men are easy', she said,' 
and I know how to get what I want. Someday, I'll hook a millionaire, and then have affairs with the people I really love.' It seemed amusing then, but it's not. Darla was a victim who thought she had power over her oppressors. Curiously, she could tolerate men a little more than women; for the former could be brought around, 'suckered', as she might have said it, whereas women were only the nasty competition, who got in the way, and upon whom her 'gifts' didn't work. No, she said, she wasn't going to be kicked around - like all the other 'dumb' women. Interestingly, a lot of radical feminists also don't like the portrayal of women as victims; but that stems from a rather savvy political strategy seeking to empower them, to reduce their sense of helplessness, to give them hope. Possibly, it's o.k. : a white lie, perhaps?

I have said the dominant inter-personal ideology is that of sexuality; but it is not at all confined to merely the private sphere. It spills over into all domains; take politics, for instance: sham as the political system is, with two Parties divided only by a common ideology, it is by far not enough to have a platform - the candidate must also satisfy the loudly unspoken demand to be sexy. Let's romp back into some recent history; Kennedy was sexy, (and rich - rich is sexier still!), Nixon was not. Reagan was not exactly sexy, but he was acerbically, and physically (even the body language) right-wing (and that is almost as sexy as being rich); poor Jimmy Carter, the nuclear engineer (always described, publicly, as a peanut farmer; his promoters were hoping that hokey is sexy, too - it isn't!) was not. No, even the cheesy smile didn't quite cut it; it was definitely not sexy. Sweet and sugary, perhaps, in an awkward sort of way, but no more. Dukakis was definitely not sexy, but Bush (Bush Sr. that is, not his later clone) though far from a sex symbol, came closer to the image: he jogged, water sported in Maine, and wore polo shirts. And, coming closer to the present, take Clinton, and compare him to poor old George (of course, exactly how sexy Clinton really was, was only to come out later, much to the chagrin of many), or closer still, compare the youthful, virile Obama to the aging McCain: you get the picture. Only in Obama vs Romney, perhaps, was there a near-'fair' match-up of such intangibles.

Bush versus Gore was a non-starter in this respect: neither had any real 'oomph' to speak of, so the typical voter found little to choose. To be sure, Bush, Jr. came a mite closer: a bit more raunchy, pick-up truck-driving Texan sport to be relied upon for the old backcountry stand-by's of beer, rifles and hunting trips. No, the media loves sexy; and so long as you are in that mold, your politics don't matter (the American polity is pure shadow-play: all important policies are formulated by corporations, their lobbies, and their think-tanks, and only purveyed through political channels and 'politicians', but more on this later).

Yes, the media are hooked on sex; but only because so are we. We all ate up Judge, and then Supreme Court Nominee, Clarence Thomas (remember him?); so did the media. Remember the issues? It was an openly disingenuous racial nomination, but that did not play; it was a right-wing, 'let's roll back civil-rights appointment', but no, that couldn't be the real focus. So what was the Thomas deal all about in hearths and homes (parental guidance suggested, like it was an R rated movie), bars 
and saloons? Yeah, you guessed it. This is America. Take the Clinton impeachment; it wasn't about politics, or ethics, or propriety : it was about sex (poor Bill: almost had us, and himself likely, convinced that oral sex isn't sex at all, with the media mostly alongside him in that pathetic feint).

The ex-Soviet Union made a critical media mistake for nearly Forty years. They pulled out unfit, heavyweight, tired old men in all of their Politbureau line-ups, and that didn't go over well at all with the slender, sexy, Time-Newsweek crews (though it was a great boon to the athletic cold-warriors of the Western world). No wonder they got a bad press for all that time. Old and ugly, as politically correct photography took care to portray them, the Russians were also tiresomely well-bred in that clumsy, ho-hum, Old-Worldly, sort of way. Until, of course, Kruschev came along with his (nearly all-American) cussing and swearing, mid-western, farmer ways: boy, did the media love to hate him! The guy was almost an Anti-Hero (which is how America loves its heroes). And then, of course, Gorbachev who, though not wholly sexy himself (he was a trifle too intelligent for that), had a wife who was - Gorbachev had to get center-billing, of course, for being the Chief of the Evil Empire, but Raisa was the real darling - and the Media buzzed, though not exactly overjoyed (after all, she was a Marxist, with a Ph.D, to boot; 'course that was all hid in small print, if it appeared at all ). But then the Slavs produced Yeltsin, twice the cusser and swearer than Kruschev could ever hope to be, and we were all bowled over. Yeltsin was sexy; he could pitch for the Yankees, barbecue with the best of them in Texas, and ride the rodeo (and all without taking his black tie off). And he was right-wing, too, and ready to sell Russia to our corporations and the IMF. We were in love (love means never having to say we want our money back, without due compound interest).

Sex-appeal is a media-must. Remember the old cold-war Olympics coverages of yesteryear? The ex-East Germans, Cubans, Koreans and the Chinese aren't/weren't sexy (they win medals, but so what?). They thumb their noses at us, hardly ever smile (IF clever media pictures are to be believed), and that definitely isn't sexy. The reformed Soviets, are/were ok, even though they licked us at the Barcelona Olympics -they'll be even more sexy now, all broken up into little states that we could whup easily at the next Olympiad, not to mention at the next round of the GATT and the WTO. But until then, we'll stick to our own, corn-fed, USDA prime hunks (recently, spectacular Chinese athletic performances are convincingly killing our all-American joy at being, as we casually presume, the only sports super-power).

The media being omnipresent, now, in its infinite internet avatar, sex-appeal is everyone's business. Even decrepit old academics, in their disheveled lairs, feel the pressure. It is not enough to know; you must communicate. To communicate, given the narcissistic young tribals who fill the class-room, you must have the right 'image'. Of course, it's all instinctive, but students who'll sleep through a stirring lecture of a tired, old man, will be all beaming and bright-eyed when a young, hip, tanned, yup-out, sells them banana oil, slinging Ray-Bans and Rockports. Have you looked at your average university president, lately? Being six-foot four and having s.a. (aside from being 
waspish, wasp-like, or just plain proto-waspish), are, I believe, amongst the principal criteria, if not the only ones. Yes, height is sexy, too. Look at corporate presidents. You know why they have to be taller; you can't be handing out pink slips to people taller than you - that would be very silly, and perhaps a bit dangerous, too. Now you know why the real president - the Jack-in-the-White-House-Box - needs to be, or at least look like, the tallest: he's the one who hands out pink slips, by the carton, to the Economy at large, when he isn't aiming missiles at Ahmednijad's, or Kim Il Sung's extended family, isn't he? I'm kidding, of course: but only partly.

Get the picture, though? Our sexuality is not fun, it does not relieve, appease, reassure, or fulfill. It is repressive; it is power play, it is loneliness, alienation, and not all that far away from sheer dementia. It is another pressure, another terrible form of insecurity, in this the most insecure of all societies (and what else could pure capitalism be?), crippling our inner selves, thwarting our normalcy; it's a fake-out that raises the promise that performance could never live up to. It's another form of estrangement from ourselves, another form of competition, another form of self-destruction, self-doubt, self-flagellation. 'They keep you doped with sex, religion, and tv', sang the ill-fated Lennon, sadly, - yes, America, he sang it to you: you who think 'you're so clever, class-less, and free' - before he was killed (funny how the pattern of killing was uniquely American: the 'lone, crazed, gunman' ploy: you'd think even the media would get tired of that old gag - from Jack Kennedy, to Bobby Kennedy, to Martin Luther King Jr., to...conspiracy? Nah, not in America, not even after the Supreme Court apparently 'legislated' the 2000 presidential election, and many other allied forces assured the 2004 one). And that's more than what a dozen Sociology courses at Columbia University could teach you (I know because I sampled almost half as many in that venerable House of Ivy League Mantras before I tossed in the towel).

Our anatomical sexuality - raw, raunchy, and explicit - is only a form of desublimation that the system is happy to tolerate, for it encourages the narcissism, the separation, the inner-directedness, the self-absorption, that spells compliance with the powers that be: passive acquiescence to iniquity, and insouciant endurance of manifest dispossessions. It is a fetishism, and objectification, of women that help breed the patriarchical traits of violence, cruelty, and aggression; values that the system needs - so long as these are turned against each other, amongst the have-littles and have-nots: men against women, white against black, and so on, leaving the rapacious corporate system untouched, unquestioned - a compensatory match-up to the brutalities of the crippling deprivations we are subjected to, day in and day out, in everyday life.

A society like ours, based on the running friction between the Producers and Appropriators, the powerful and the powerless, those who work and those who direct, command, and control the work process, needs many safety valves to redirect revolt, to siphon off discontent, to dissipate the surplus consciousness, that might otherwise turn to question, criticize, and struggle. Our sexual fantasies are the aspirins that we are to take to bed, to forget the pain of it all for another night, to retire into our private 
hells where we still continue to nurture our ever so forlorn hopes of a purely private paradise (only guaranteed, as far as I know, in a Mormon heaven where each male is served by several pliant women).

The more genital sexuality is internalized, marketed, and made into common, vulgarized ideology, the further we move away from the spontaneous eroticism that desublimation destroys permanently. In less marketized, Old world societies there is, true, more hypocrisy, more repression, of the overt, legal kind, in all matters of unlicensed sexuality, breeding a sublimation, a cover-up, where a discreet, even dissembling, veil is placed over the matter as a private issue between man and woman (usually husband and wife). Not even vaguely is it a public convenience to be dissected clinically, exposed in films, or parleyed in explicit fiction. But, quite inherently, these forms of sublimation, dissociated from their violent social contexts (and there are societies where one can still, legally, in Old Testament fashion, be stoned to death for adultery; you guessed it - not the man, but the woman) are not destructive of sexual fulfillment - indeed, are capable of enhancing it, in the direction of making it more heady, more fervid, more delirious. The stolen kiss, the unexpected touch, the rare, forbidden, secret, union (in the Romeo-Juliet vein) have an eroticism, an excitement, a quality of breathless passion, that a life-time subscription to the entire Penthouse genre could not hope to deliver. For true eroticism is not genital but polycentred and polymorphous, not rabid, and raunchy, but composed of poetry, fancy, dream and romance, extending beyond the ultimately irreducible ennui of body parts ('A sweet disorder in the dress kindles in clothes a wantonness', sang a late feudal, English poet; and he was getting close to the point, although trapped in the prison of traditional male/female dichotomies).

It is not objectified, because men and women can both share in it; it is not obsessive, for social life has not been radically reduced to the alienated individual's search for private fulfilment; and it is not destructive because, fundamentally, it is not tied to competitiveness in matters of pure physicality. It has a wholeness that nurtures, a textured richness that leaves all to the imagination, a joyfulness that will not wither past the act. No, Kamala, in India, is not more 'liberated' than Darla; she has more inhibitions, hang-ups, restraints, social and legal, taboos old and new, and deprivations, material and emotional. But she is not, emphatically, more unhappy than Darla; her life, though circumscribed, is whole (or more whole), if not always wholesome. She has not yet been bred out of the matrix of social relations that work both as prison, yes - but also as haven, sanatorium and sanctuary.

On a summer visit to India, a long time ago, I observed a pageant, nay a sort of a passion-play, speaking to just this amplitude of the social psyche, and one played out no doubt daily on the harsh streets of New Delhi, and its environs, under a pitiless Indian sun. The city, parasitic like all cities, draws in village laborers, displaced, ruined peasants in the main, like California draws in Mexicans, and for quite similar reasons; and they slave at tasks, but borderline debt-peons, both burdensome and oppressive, for pennies, sometimes even less - hapless victims of the entrepreneur- 
sharks that prey ruthlessly upon their misfortunes. Always seeking out the horrors of social existence (and finding them, sad to say, only too easily), at the core of which, however, rest the only true glimmers of real hope I can swear to, I came upon one group of migrant workers, travelled from a distant village economy, displaced by the fell hand of modernity, tarring a road (with the thermometer at 110 degrees in the shade), barefooted, scantily clad, and covered from head to foot in a layer of grey soot that rendered facial features virtually indistinguishable.

Within that group of ragged human chattel, seared by sun and tar inclusive, were a young couple that caught my eye as they went about their arduous labors silently, and continuously, until a kindly dusk was to come to deliver them from their grim mortifications of both soul and flesh. The young woman wore a traditional headwrap that bore down, as intended, to form a sort of a hood covering her face as rustic modesty required of her; every time she passed her husband - both carrying enormous, dripping, vats of boiling tar (scalding spills from which ran down their limbs ever so often, all but unnoticed) - the hood would partly, ever so slightly, lift, and their eyes would meet for an instant, as they paused momentarily, almost involuntarily, and yet without expression, greeting, gesture, or grimace.

No casual eye could have gleaned their intimacy, so completely was it hidden from a world that had doomed them, lifelong, to indelibly unrequited toils; but I sat and watched that secret, sacral, exchange of heavily veiled sentiment, pregnant with a hundred meanings, defying the torments bleaching their young years, a mesmerized voyeur, all day, until the bitter sun finally relented and allowed a healing dusk to settle around them, like balm sent of a derelict heaven. Day-labors at an end, they adjourned to the shade of a clump of trees, only yards away from their worksite, under which, joyous in this brief respite of togetherness, with the entire family united again, they would spend the night in peace, rest, and simple revelry. That was (another genre of) Kamala - a peasant Kamala with even more circumscribed freedom-, to be sure, and her mate; and that evening she would cook their pitiable fare with the other women, later maybe sing with them, eyes shining excitedly, wide smiles creasing the (still) dust-stained mouth, while all the while he sat watching her in contentment, eyes shining back in return, slouched under the glittering stars with the older men, smoking wild cheroots, suffused with helpless laughter at the same old stories being told of the ever strange ways of those incomprehensible city folk who sped about them on wheels. She would have been fourteen, he barely a year or so older. Perhaps they were affinal kin, playmates in childhood, predestined to be married, and now, forever, companions in age. And they would, of course, thanks to India's now secure and solid embrace of capitalist modernity, know a life filled only with ceaseless drudgery and the stupefying terrors of a chill, remorseless penury, together when apart, apart when together; but today, now, at home, under the stars, by the spreading trees, with no roof to block the skies, but a blink away from a busy thoroughfare, in an alien city, yet within their all too familial world of acid certainties, surrounded by precious possessions that could all be wrapped inside a pocket handker- 
chief, with no thoughts of the desperate privations, dawn would visit upon them all over again, in the privacy only of their hearts, and the sanctuary only of the purest sentiments, they would not, indeed could not, be bitter, unhappy, or discontented. Not ever. We lack, for having lost it irretrievably, the measure of that unutterable intimacy, of that speechless exultation, our bovine convenance unable to grasp the sparkled depths of that irrevocable love, of that silent but engulfing litany of irrepressible feeling.

The march of that we call 'civilization' (a poignant misnomer) both disguises the new and strips veils away from the old, leading ultimately to the disenchantment, the debriefing, of the world. In part, it is progressive, because we rationally grasp the social bases of behavior; in part, it is repressive because it is often inappropriately reductionist, and manipulative, as with sexuality. To take away from the mystery of life is not always to enhance the quality of it; for many things creative stem from the sheer languor of this state of semi-consciousness - poetry, for instance, or art, even music. Human sexuality, similarly, can be dream-like, complex, textured, many-layered, and beautiful; to reduce it to the sweaty interaction between human organs, as in the average porn film, is to radically destroy our capacity for exultation in a chilling, uncharming, joyless, world. Our form of sexual liberation cripples and maims, reduces and retards, stifles and suppresses.

I once stood, early in my misconceived North American meanderings, by a busstop in Times Square, as the proprietor of one of the little sorry dens of human abasement that litter the area parted a curtain, deliberately, so passers-by could see the images on the video screen inside. I will never forget it because I had just arrived in America, and had never seen porn before, and because its dehumanization is with me still, in the form of a sickening sensation, starting at the very pit of the stomach, and then rising to consume all the senses. The film showed a woman orally stimulating a dog to the end; and even now, decades later, I find it hard to like New York. In a truly human society, wrote Bertrand Russell, the English humanist and philosopher, flogging would be impossible, because it would be unthinkable to get anyone to flog another, for any inducement whatsoever; I had just seen far worse than the unthinkable, on an otherwise unremarkable city street. Porn is not about sex, as every porn star knows, but about degradation, humiliation and violence; and you, my effete, middle class, middle-aged, suburbanite reader, clutching your girlie magazine hid behind business papers, on the commuter train back home, with wife and kids awaiting, must know all this. This is your secret, vicarious, personal requital for all the hurts in your life, for all the times you've been rolled over, passed up, and pushed around; you think you know how to get relief, closeted with your pet fetish- but you're not even close.

But, let's bring all of this home, in a more normal setting. Let me tell you the fairly unexceptionable, but heavily edited, story of an Italian duo, let's call them Gino and Gina, I'm (was) friends with. They went on a visit, a first visit, to London, lasting all of a long week-end, and came back quite thrilled with it all. I picked them up (they 
were neighbors) at the airport, and dropped them home. Inadvertently, Gina had left her journal in the car; and I read it over - under license of a philosopher! - not a little ashamed. Here's how, in abbreviation, their trip was logged:

8.00 AM airport to hotel

8.30 AM breakfast (love the muffins)

9.00 AM sex (ok)

10.00 AM Tour Bus to The Tower

12.00 noon lunch in hotel (great chops)

12.30 PM sex (no comment)

1.30 PM Tour Bus to Br.Museum

4.00 PM Tea in Hotel (great scones)

4.30 PM sex (so?)

5.30 PM Tour Bus London Evening

7.30 PM Dinner (disgusting Yorkshire Pudding)

8.30 PM sex (I wonder...)

That was saturday's schedule; sunday morning was more of the same, but I pick up the (partially expurgated) narrative sunday afternoon (they are to leave the next morning).

4.00 PM Tea (clotted cream: yumm)

4.30 PM sex (hmmm)

5.30 PM Tour Bus London by Night

8.00 PM Dinner in Hotel (fabulous ratatouille)

9.00 PM sex (what is going on...?)

The lavish exhibits of British History, Antiquities, and Empire, (such as they are) did not impress our two-some, though the meals were quite passable, getting favorable mention; but the sex, according to Gina, was not at all up to par. Why go all the way to England for more food and sex, one might think, when the nearest, neighborhood, Holiday Inn/Hilton could cut close to where they were at?; in point of fact, London could just as well have been Timbuktu, for all the difference it would have made. And the last I met Gino, it was over, he told me; Gina had 'moved on'. Perhaps I should have warned him, I had, after all, the scoop on Gina's mind. There wasn't a great deal on it, as I recall.

We are become blind to our own talents, capabilities, and potentialities, and insensitive to the great beauty, the great suffering, and the great drama of human exploits in this unfathomable, pre-given, natural universe. Corporatism, in a market framework, destroys the fine threads that link the delicate fabric of our social being; our social arena shrinks, our social relations atrophy. We are defined by our narrow, miserable tasks, and live within the crippling context of that alien division of labor where we must be cogs, most of us, never to rise up to higher apprehensions. Food, sex, and entertainment, might well be the happy, cheer-bestowing, adjuncts of a sane, 
Convivial society; they are even more the desperately needed Anodyne for an Insane one. They are ghost-like substitutes, phantom stand-ins, ersatz surrogates, for the real thing. They can neither fulfill, appease, nor uplift; but they will return us, again and again, especially as the boundless optimism and energy of youth subsides, to the quiet desperation of our empty lives.

We need not surrender, despairingly, to unfeeling, insensate, obtuse sensuality (the going only gets tougher when the gonads get going); things are bad enough, as it is, to go seeking purely self-inflicted tortures. We could loosen up, thaw out, and unfreeze our arteries; for life is but one chance (and not even a full one at that, for many) to experience the inexhaustible richness of this many-splendoured, but far too fleeting, universe. We could give up the grim Grindstone - as and when possible - to lift our visions, reach for the sky, and dream a little; it is all to be over too soon, anyway. The bestial, as every well-marbled, well-hung, Sammy six-pack knows, is only too easily within reach; but it is never true refreshment in and of itself. The searing appetites of the flesh are only a scourge to the spirit, withering and decaying it, sinking us even lower into the mire of rank discontent when not in complement with higher Nourishment for our empyreal, spiritual selves whose deepening thirst may not be slaked, ever, by carnal ravishments alone. So for the likes of Darla and Gina, I suggest a little yoga, a little inward exploration, a safari, of sorts, into the lush, unexplored preserves of the interior; it will get them there, wherever it is they may think they want to go, faster, cleaner, cheaper, and safer: the creation of new energy being even more gratifying than its vapid, desultory expenditure. Life, in affirmation of its primal mysteries, is the biggest rush we can ever hope to feel - and we could easily take time off from the rigors of the wretched treadmill to sample it sometime, unmediated by the demons of greed, ambition, and lust. It is, I think, even in this forbidding wasteland of near-total misanthropy that is America, still not too late for such simple, altogether venial, redemptions. 